\title{
Study on the browning and structure properties of fresh-cut Chinese water chestnut (Eleocharis tuberosa)
}

\author{
Xiaoyan ZHANG ${ }^{1}$, Yong PENG ${ }^{1 *}$, Qingguo WANG ${ }^{1}$
}

\begin{abstract}
In this paper, the microstructure, water properties and browning control of Chinese water chestnut (CWC) after harvest were studied. Results showed that the tuber cell contained a large number of starch granules (5-10 $\mu \mathrm{m}$ for each one). The water-holding capacity of tuber cell was weak and T2 relaxation time was 28.5-75.6 ms. Sucrose was the main sugar component in Chinese water chestnut, which account for $84.8 \%$ of total sugar. In addition, potassium sorbate, green tea polyphenol and chitosan decreased the browning of fresh-cut CWC compared with the other anti-browning agents such as acetic acid, citric acid, oxalic acid, vitamin $\mathrm{C}$ and thyme oil. Moreover, chitosan coating combined with potassium sorbate and green tea polyphenol delayed weight loss and decay of fresh-cut tubers, also maintained a higher soluble solids and ascorbic acid content. The study provided an alternative method for controlling CWC browning, which would be helpful for the application of anti-browning agents in CWC processing.
\end{abstract}

Keywords: Chinese water chestnut; microstructure; relaxation time; browning control; chitosan.

Practical Application: Provide a better understanding in the texture and anti-browning agents of Chinese water chestnut.

\section{Introduction}

Chinese water chestnut (CWC, Eleocharis tuberosa) is one of most popular food for Asian people due to its special taste, texture and medical function (Klockeman et al., 1991; Mudahar \& Jen, 1991; Peng \& Jiang, 2006; Peng et al., 2013). Some researchers have focused on the differences in quality properties of CWC during storage, particularly in texture and browning field (Peng et al., 2013; Wang et al., 2008). The texture of fleshy fruits and vegetables is of primary concern for the whole production to consumer chain. The texture depends on several factors such as internal turgor pressure, characteristics of water within cell compartments, thickness of cell walls, size of cells and pores, and orientation of cells in the tissue (Winisdorffer et al., 2015). Mudahar \& Jen (1991) found that the texture was different from jicama through histological examination. CWC had uniform cell sizes and intercellular spaces with relatively more thick cell walls than jicama. Klockeman et al. (1991) showed that pectin and hemicellulose are the main components in CWC resulted in crisp taste. However, to date, there are no reports specifically on the relationship of microstructure, sugar composition and water status in tissue cell of CWC. Water status and distribution in plant tissue can be assessed by MRI (Werz et al., 2011). However, few studies have focused on the water status changes of CWC during storage.

Browning is a common phenomenon in fresh-cut CWC, which greatly reduced the shelf life and commercial value of fresh-cut CWC. Some treatments such as citric acid (Jiang et al., 2004), salicylic acid (Peng \& Jiang, 2006) and hydrogen peroxide (Peng et al., 2008) could inhibit fresh-cut CWC browning. Pan et al. (2015) investigated the browning products and identified some substrates such as eriodictyol, naringenin, sucrose and ethyl D -glucoside in fresh-cut CWC. However, chemical preservation easily leads to the formation of toxic substances. Many chemical reagents have been banned in the use of fresh-cut fruits and vegetables. Therefore, novel preservation agents are required for the preservation of fresh-cut CWC. Green tea polyphenol is a natural antioxidative substance, but green tea polyphenols as antioxidants used in CWC has not been reported. Chitosan, as a new natural polysaccharide material, has been increasingly studied in the food industry due to its excellent film-forming properties, antioxidant properties, physical and mechanical properties (Hosseinnejad \& Jafari, 2016; No et al., 2007; Ojagh et al., 2010). However, the application of chitosan still needs to be developed for improving the quality of fresh-cut CWC during the storage.

In this paper, the microstructure, sugar composition and tuber tissue water types of CWC were analyzed. In order to prevent from fresh-cut CWC browning, chitosan, plant essential oil, vitamin $C$ and green tea extracts were selected to investigate the effects on browning and quality parameters during storage.

\section{Materials and methods}

\subsection{Materials}

Chinese water chestnuts (CWC; Eleocharis tuberose cv. Anhui) were obtained from a commercial market in Shanghai. Tubers were selected for uniformity and size, and any bruised or diseased fruits were discarded. Crab chitosan (molecular weight: $420 \mathrm{KDa}$, 
deacetylated degree: $88.1 \%$ ) was purchased from AK Biotech Ltd. (Shandong, China). Glycerol, acetic acid, citric acid, oxalic acid, sodium chloride, potassium citrate, vitamin C, fructose, glucose, sucrose were purchased from Sinopharm Chemical Reagent Co., Ltd. (Shanghai, China). Thymus vulgaris essential oil (thymol: $57.24 \%$, p-cymene, $18.91 \%$, carvacrol: $2.82 \%$, linalool, $2.03 \%$ ) used in this investigation was provided by Shanghai Tiamay Aromatic Plant Sci. \& Tech. Co. Ltd. (Shanghai, China). Green tea extract (green tea polyphenols: $99.9 \%$, total catechins: $81.2 \%$, EGCG: $51.7 \%$ ) was provided by Fuzhou Corona Science \& Technology Development Co., Ltd. (Fujian, China).

\subsection{Scanning Electron Microscopy (SEM) observation}

The tubers were previously cut into $2 \mathrm{~mm}$ thick slices and were quickly freezed in the $-50{ }^{\circ} \mathrm{C}$ vacuum freeze dryer. Then the slices were fractured in liquid nitrogen. Prior to observation, samples were mounted on metal grids using double-sided adhesive tape and coated with gold under vacuum. Microstructure observations of surface and cross-section were carried out using a JSM-7401F field emission scanning electron microscope (JEOL Ltd., Akishima, Japan) at $5 \mathrm{kV}$.

\subsection{Nuclear Magnetic Resonance (NMR) detection}

The tubers were cut into slices with $2 \mathrm{~mm}$ thick and $10 \times 30 \mathrm{~mm}$ size. The slices were placed in the sample tube of magnetic resonance imaging analyzer (NMI20-Analyst, Shanghai Niumai Ltd., Shanghai). Parameters are set to the frequency of $23.0 \mathrm{MHz}, 90^{\circ}$ pulse width of $16.5 \mu \mathrm{s}, 180^{\circ}$ pulse width of $33.0 \mu \mathrm{s}$, half echo time $105 \mu \mathrm{s}$, cumulative sampling 8 times. After the analysis, the slices were placed in the $105^{\circ} \mathrm{C}$ drying oven for $24 \mathrm{~h}$ in order to determine water content. Six replications were carried out for fresh tubers.

\subsection{Sugar composition determination}

About $10 \mathrm{~g}$ of fresh tuber samples were grinded in double distilled water, and then were heated in water bath for $20 \mathrm{~min}$ at $80^{\circ} \mathrm{C}$. After cooling, the samples were centrifuged at $10000 \mathrm{~g}$ for $10 \mathrm{~min}$. The residues were again extracted and centrifuged with $20 \mathrm{~mL}$ double distilled water at the same condition. The supernatants were combined and the final volume was made up to $100 \mathrm{~mL}$. Three repetitions were performed by liquid chromatography (Perkin Elmer 200 high performance liquid chromatography, American PE Ltd.) equipped with differential refraction detector for the tuber sample. Chromatographic analyses were performed in a Shimadzu Inertsil HPLC amino column $(250 \times 4.6 \mathrm{~mm}, 5 \mu \mathrm{m})$ at $40{ }^{\circ} \mathrm{C}$ with a mobile phase of acetonitrile/water (75:25, v/v) at a flow rate of $1 \mathrm{~mL} / \mathrm{min}$. The injection volume was $10 \mu \mathrm{L}$ for each sample. The sugar content was quantified through a calibration curve built with pure fructose, glucose, sucrose standards samples and results were expressed by milligram of sugar in per gram of fresh weight $(\mathrm{mg} / \mathrm{g})$.

\subsection{Anti-browning experiments}

In order to select the best anti-browning agents, some anti-browning substances such as acetic acid, citric acid, oxalic acid, vitamin C, green tea polyphenol, sodium chloride, potassium sorbate at $1 \%(\mathrm{~m} / \mathrm{v})$ and thyme oil at $0.05 \%$ concentration were selected for browning inhibition and decay of fresh-cut tubers. The control tubers were dipped in distilled water for $2 \mathrm{~min}$ by following the same procedure. Subsequently, these tubers (24 tubers each treatment group) were placed in plastic plate (6 tubers for each plate) covering the polyethylene film and stored at $4{ }^{\circ} \mathrm{C}, 85 \%$ relative humidity (LHS-100CL Constant Temperature and Humidity Box, Shanghai Yiheng Instrument Co., Ltd., Shanghai, China) for 16 days. Final tuber appearance was observed and photographed at the end of storage.

From the above experiments, green tea polyphenol and potassium sorbate were proved to be the best agents in controlling fresh-cut tubers browning. Subsequently, chitosan was combined with green tea polyphenol and potassium sorbate for better inhibiting browning and decay. The experiments set: distilled water (Control), 1.5\% chitosan solution $(\mathrm{CH}, 1.5 \mathrm{~g}$ chitosan dissolved in $100 \mathrm{~mL}$ of $0.5 \%$ acetic acid solution, with $0.5 \mathrm{~g}$ glycerol as plasticizer), $0.2 \%$ green tea polyphenols $/ 0.2 \%$ potassium sorbate (GT-PS), $1.5 \%$ chitosan $/ 0.2 \%$ green tea polyphenols $/ 0.2 \%$ potassium sorbate (CH-GT-PS). Each treatment (48 tubers) was applied by dipping water chestnut in its respective solution for $2 \mathrm{~min}$. The storage procedure was the same as the above after $4 \mathrm{~h}$ air-drying. Three repetitions were done for each treatment.

Weight loss was performed by using a $0.001 \mathrm{~g}$ electronic balance after the treatments and results expressed as percentage of the initial weight. The decay incidence was determined for a visible lesion in fresh-cut CWC surface.

Total phenol and flavonoid were determined by grinding tubers in ice bath according to Zhang \& Quantick (1997). The tubers $(2 \mathrm{~g})$ were extracted with $1 \% \mathrm{HCl}$-methanol solution $(10 \mathrm{~mL})$ at room temperature for $2 \mathrm{~h}$. The homogenate was filtered and washed, and the filtrate was diluted with $1 \% \mathrm{HCl}$-methanol to $50 \mathrm{~mL}$. Absorption of the diluent was measured at $325 \mathrm{~nm}$ for flavonoids, and $280 \mathrm{~nm}$ for total phenolics. Flavonoid contents and total phenolics were calculated from a standard curve made with rutin and gallic acid, respectively.

The tuber color was determined by a WSC-S colour difference metre (Shanghai Precision \& Scientific instrument Co., Ltd., Shanghai, China). Measurements were performed by placing tubers over the standard and four repetitions were conducted for each treatment. The CIE laboratory scale was used to determine $L^{*}, a^{*}, b^{*}, \Delta E$.

Soluble solids content (SSC), titratable acidity (TA), and ascorbic acid of tubers were analyzed in the initial time and at the end of the $20 \mathrm{~d}$ storage. SSC were measured with the pressed juice of each tuber by means of a hand-held sugar refractometer (WYTJ; Chendu Optical Apparatus Co. Ltd., China). Titratable acid was determined with $0.1 \mathrm{M} \mathrm{NaOH}$, and the results were expressed as percentage malic acid. The 2, 6-dichloroindophenol titrimetric method was used to determine the ascorbic acid contents. The results were expressed in milligrams of ascorbic acid per $100 \mathrm{~g}$ fresh weight.

\subsection{Statistical analysis}

All results were carried out in three replicates except for special statement and expressed as the mean \pm standard deviation. The data were analyzed by ANOVA using SPSS 
software (version 17.0, Statistical Package for the Social Sciences Inc., Chicago, USA) and differences among mean values were processed by the Duncan's multiple range tests. Significance was defined at $\mathrm{p}<0.05$.

\section{Results and discussion}

\subsection{Morphology of tuber tissue}

The edible part of CWC is the tuber which has brown skin and white pulp. As shown in Figure 1A, there were many irregular depressions in the epidermis of CWC by the SEM observation, which might be the residual lenticels retaining on the outer skin of tuber. The epidermal cells were arranged closely (Figure 1A and B) and inner cells were bigger than the outer. The inner cells of CWC tuber in which contained a large number of starch granules (Figure 1C) was regularly arranged. Moreover, the starch granules shape was irregular oval with a diameter about 5-10 $\mu \mathrm{m}$ (Figure 1D), which was similar to the size of cassava starch granules $(7-11 \mu \mathrm{m})$ (Chen et al., 2011). The size and number of starch granules could be related to the quality characteristics of CWC.
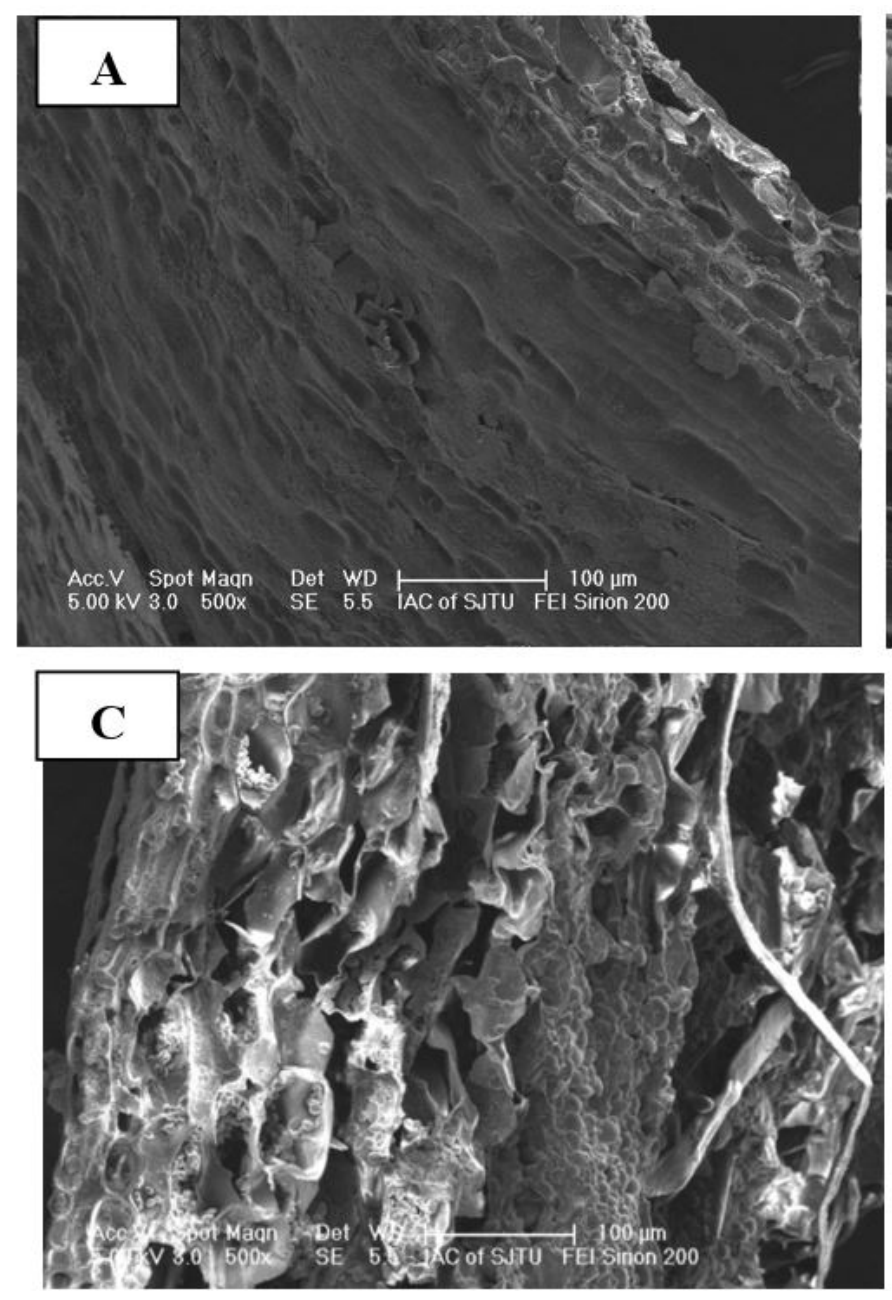

\subsection{Water composition}

Nuclear magnetic resonance (NMR) is a physical phenomenon in which nuclei in a magnetic field absorb and re-emit electromagnetic radiation. This electromagnetic energy is at a specific resonance frequency which depends on the strength of the magnetic field and magnetic properties of the materials. In food industry, NMR, a non-invasive and non-destructive method, can provide visualization of localized morphological changes in the interior portions and water distribution in intact plant tissues (Gonzalez et al., 2001; Zhou et al., 2008). Study on the Huanghua pear showed the higher moisture content, the brighter nuclear magnetic resonance images (Zhou et al., 2008). T2 relaxation time was related to the water content and distribution in tissue cell (Winisdorffer et al., 2015; Zhou et al., 2008).

In our study, T2 relaxation time by inversion fitting of NMR signal revealed the physical properties of water molecules and water distribution in CWC tuber tissue. As shown in Figure 2, the water in tuber tissue was consisted of free water and bound water. Free water accounted about $95.1-98.3 \%$ of total water with very little bound water. T2 relaxation time of bound water in CWC tuber was 28.5-75.6 ms, which was much later than other fruits

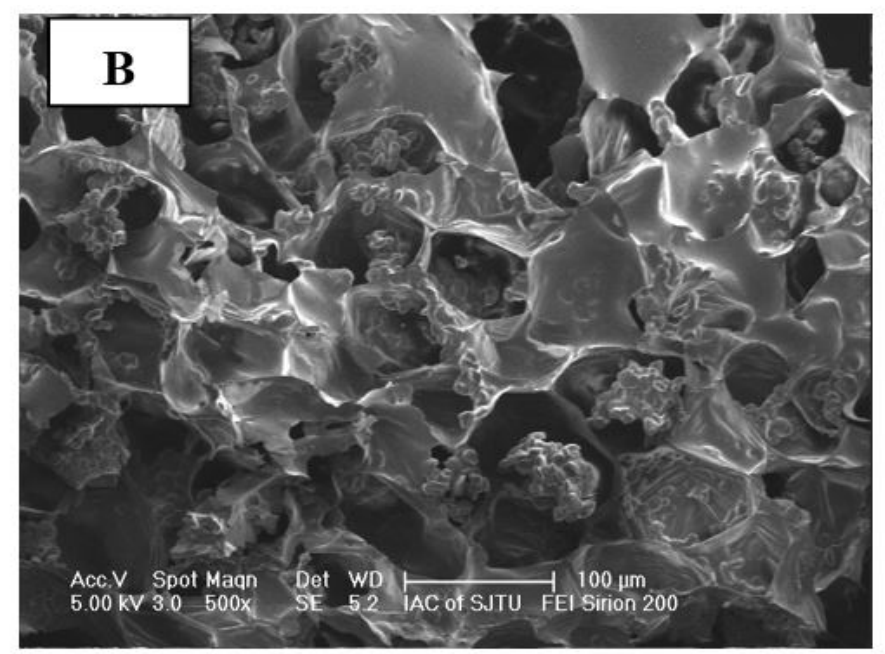

Figure 1. SEM micrographs of the surface and interior of Chinese water chestnut. (A) Epidermis; (B) Epidermal tissue; (C) Interior; (D) Enlargement of starch granules. 


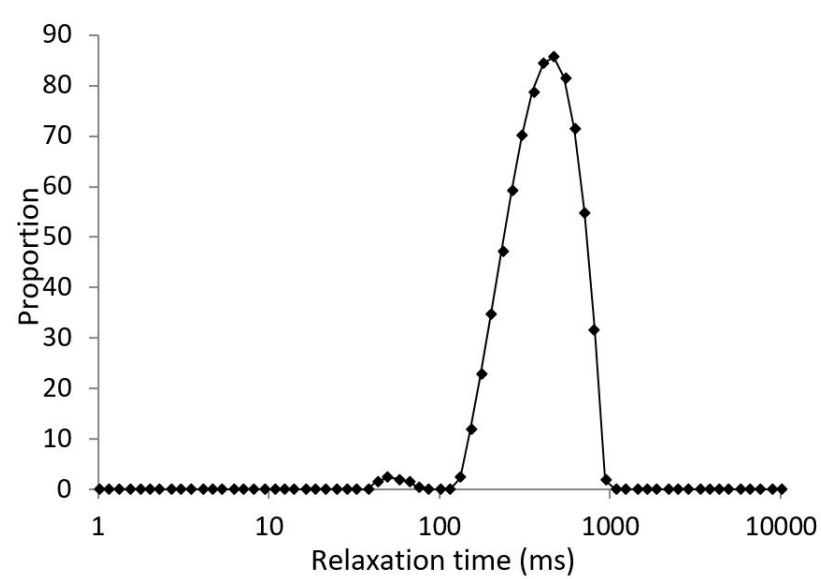

Figure 2. NMR signal curves of fresh Chinese water chestnut.

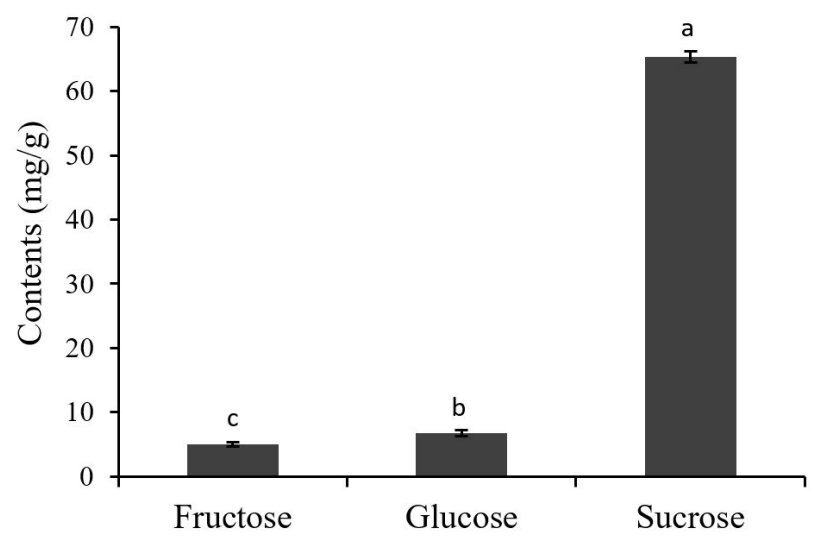

Figure 3. Sugar composition of Chinese water chestnut. Different letters $(a, b, c)$ in the same column indicate $\mathrm{p}<0.05$ significant differences. such as apple (2.3-3.2ms) and potato (20.0-30.0ms) (Werz et al., 2011). This showed that CWC had weak water-holding capacity and was easy to dehydration and shrinkage during storage.

\subsection{Sugar composition}

CWC contains starch and oligosaccharides in its tuber tissues ( $\mathrm{Wu} \& \mathrm{Yu}, 2015)$. However, compositions and types of sugars in CWC have not been reported. In our experiment, it can be seen from Figure 3 that the main sugar in CWC was disaccharide. Sucrose content account for $84.8 \%$ of total sugar was $65.3 \mathrm{mg} / \mathrm{g}$, while the contents of fructose and glucose were only $5.0 \mathrm{mg} / \mathrm{g}$ and $6.7 \mathrm{mg} / \mathrm{g}$, respectively. This was similar with the reports on sweet potato (Picha, 1985) in which the contents of sucrose, fructose and glucose were $41.0 \mathrm{mg} / \mathrm{g}, 3.0 \mathrm{mg} / \mathrm{g}$ and $2.4 \mathrm{mg} / \mathrm{g}$, respectively. But the sugar compositions were different from some fruits such as cherry, apple (Füzfai et al., 2004). The special sugar compositions and types of CWC contribute to the special sweet taste.

The values are expressed as means \pm standard error. Different letters indicate significant difference $(\mathrm{P}<0.05)$ in four groups.

\subsection{Effects of anti-browning agents on CWC quality}

As shown in Figure 4, anti-browning agents could significantly affect the browning and rot of fresh-cut CWC. Acetic acid, potassium sorbate and green tea polyphenols had best effects on browning inhibition in all substances. However, potassium sorbate, green tea polyphenols, thyme essential oil and vitamin $\mathrm{C}$ were more effective in inhibiting decay occurrence. Therefore, for further experiments, a combination of potassium sorbate, green tea polyphenols and chitosan coating were used for better browning and decay inhibition of CWC.

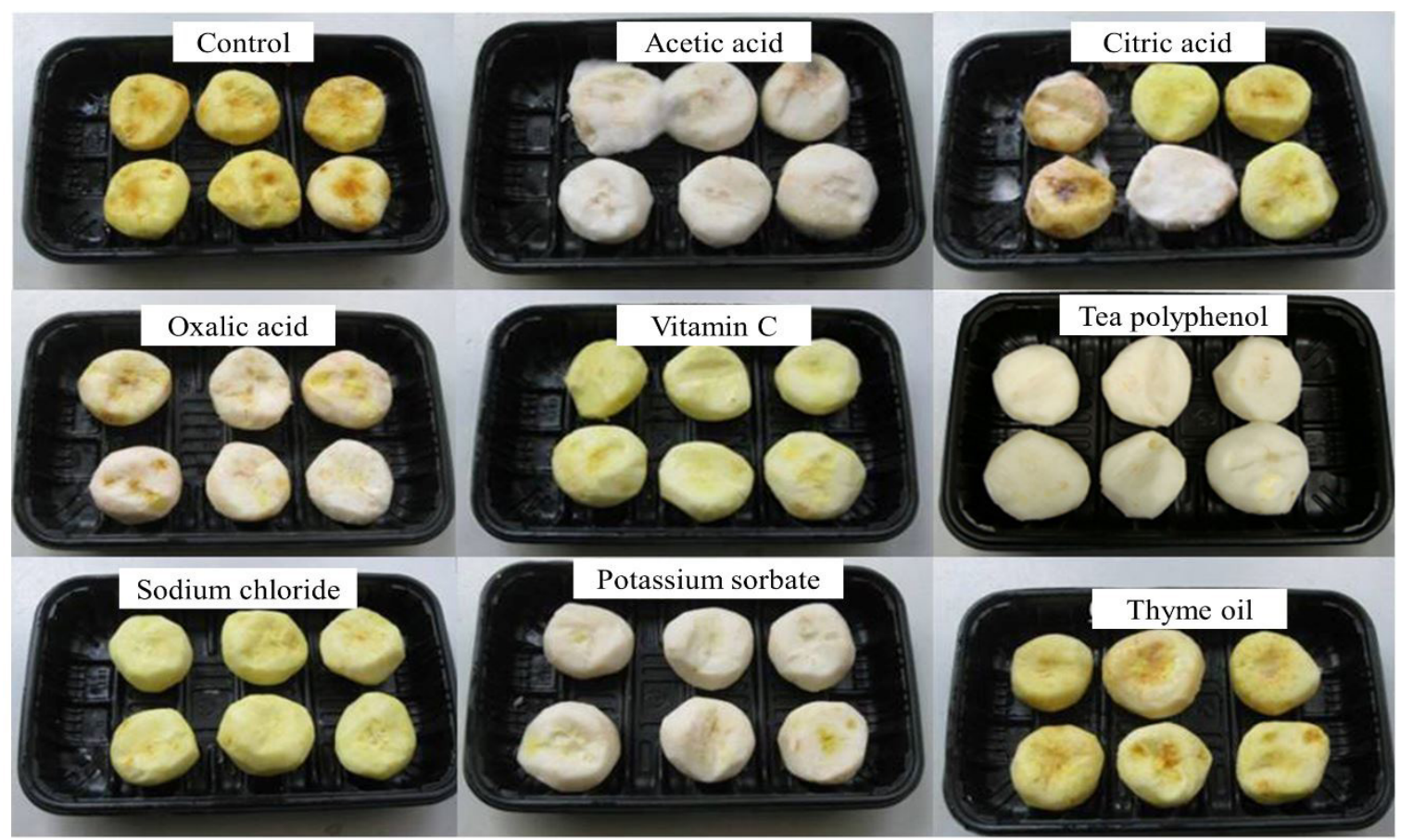

Figure 4. Effects of different anti-browning compounds on the browning and decay of fresh-cut Chinese. 
Storage parameters of fresh-cut CWC such as weight loss, decay incidence, total phenol, flavonoid were showed in Figure 5A-D. The results showed weight loss was enhanced with the increase of storage time, which reached 3.5\% for the control after $20 \mathrm{~d}$ of storage (Figure 5A). However, the tubers coated with chitosan or GT-PS showed a significant $(\mathrm{P}<0.05)$ decrease in weight loss compared with the control, especially for CH-GT-PS. This could be attributed to the water barrier characteristic results from the film formed after solidification of chitosan coating (Ojagh et al., 2010; Peng et al., 2013).

Figure 5B showed the decay incidence of fresh-cut CWC during cold storage in all treatments. Decay was found at 8 th day in control group, and gradually increased to $98 \%$ at the end of 20th day. However, these treatments such as CH, GT-PS, CH-GT-PS were more effective to reduce decay incidence than the control. After 20 days of storage, the decay incidence of $\mathrm{CH}$, GT-PS, CH-GT-PS were $80 \%, 86 \%$ and $67 \%$, respectively. Usually, chitosan coating could reduce the decay incidence of fruits and vegetables, such as strawberries (Park et al., 2005), tomatoes (Liu et al., 2007) and papaya (Ali et al., 2010). The inhibitory effects of chitosan on decay incidence might be associated with the direct fungitoxic property against the pathogens (Liu et al., 2007). However, the mechanism of potassium sorbate and green tea polyphenols in reducing the decay incidence could be attributed to organic acid and polyphenol content, respectively.
As shown in Figure 5C, no significantly changes in the total polyphenols of control tubers were observed during the whole storage period. Chitosan coating significantly $(\mathrm{P}<0.05)$ decreased the total polyphenol content after $4 \mathrm{~d}$ storage. However, $\mathrm{CH}-\mathrm{GT}$-PS and GT-PS treatments significantly $(\mathrm{P}<0.05)$ increased the total polyphenols content to $0.6 \mathrm{mg} / \mathrm{g}$ and $0.5 \mathrm{mg} / \mathrm{g}$ after 4 days of storage, respectively. The rapid increase in total polyphenols content could be attributed to phenolic compounds found in the green tea, thus caused the increase of total polyphenols. Taghvaei et al. (2014) also found that natural antioxidants extracted from plant resources contained many phenolic compounds and had better antioxidant activity. As shown in Figure 5D, flavonoids in control tubers were gradually increased from $0.1 \mathrm{~g} / \mathrm{g}$ at $0 \mathrm{~d}$ to $0.3 \mathrm{mg} / \mathrm{g}$ at $20 \mathrm{~d}$. While the flavonoid contents were significantly $(\mathrm{P}<0.05)$ decreased by all the treatments such as $\mathrm{CH}$, GT-PS, $\mathrm{CH}-\mathrm{GT}-\mathrm{PS}$ during storage. Chitosan and tea polyphenols inhibited the increase of flavonoids in CWC may be associated with the extremely strong antioxidant capacity of themselves (Ali et al., 2010; Bancirova, 2010).

Values are expressed as means \pm standard error. Different letters in the same column indicate significant differences $(\mathrm{p}<0.05)$.

The colour changes of fresh-cut CWC treated by green tea, potassium sorbate and chitosan coating were shown in Table 1. The results showed that both GT-PS and CH-GT-PS had higher $\mathrm{b}^{*}$ and $\Delta \mathrm{E}$ than that of control group at $0 \mathrm{~d}$ storage time. This was mainly related to the yellow colour of green
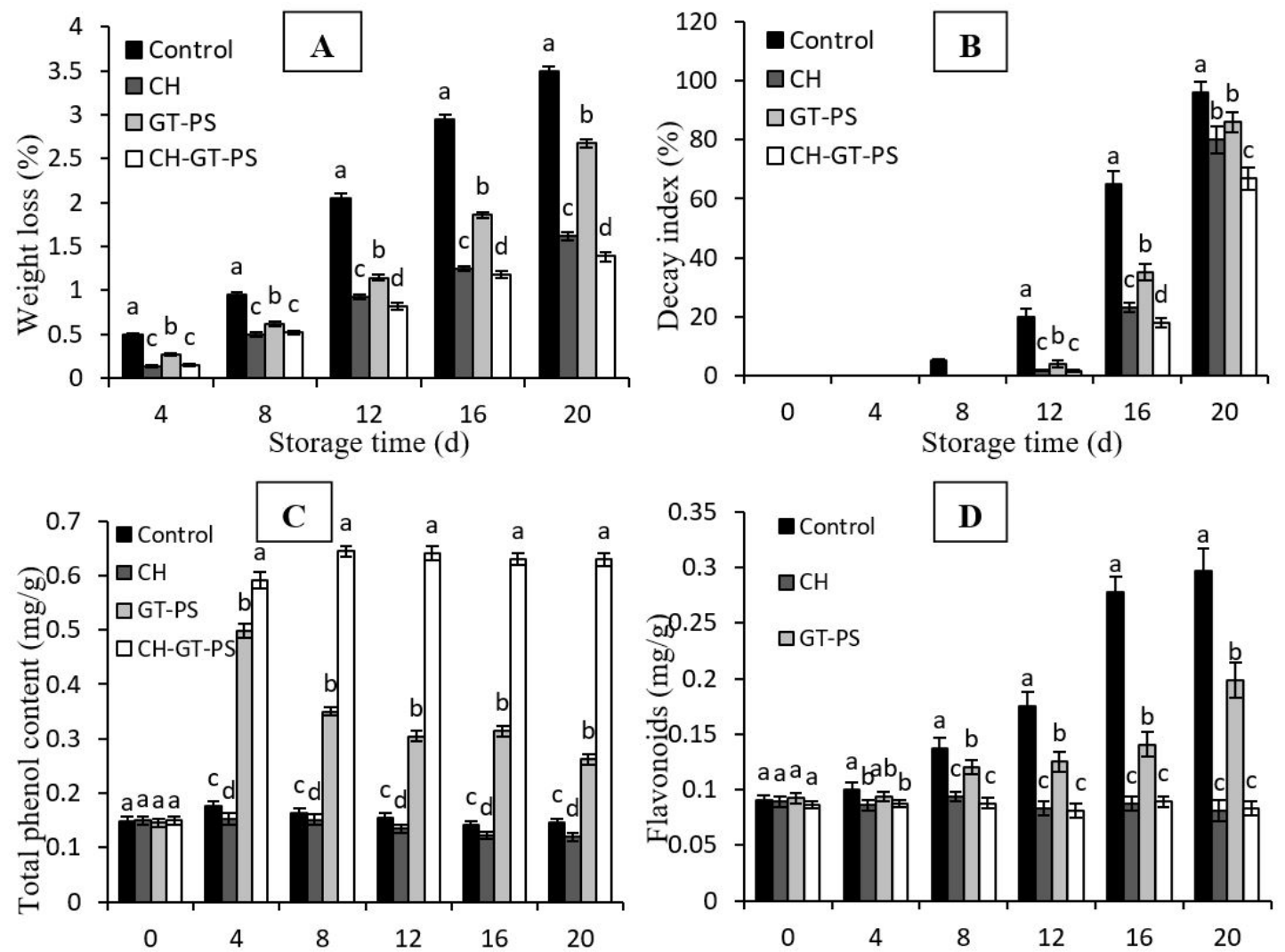

Figure 5. Effects of green tea extracts, potassium sorbate and chitosan coating on weight loss (A), decay (B), total phenols (C) and flavonoids (D) of fresh Chinese water chestnut. The values are expressed as means \pm standard error. Different letters indicate significant difference $(\mathrm{P}<0.05)$ in four groups. 
Table 1. Effects of green tea extracts, potassium sorbate and chitosan coating on colour of fresh-cut Chinese water chestnut.

\begin{tabular}{|c|c|c|c|c|c|}
\hline Storage time $(\mathrm{d})$ & Treatments & $\mathrm{L}^{*}$ & $a^{*}$ & $b^{*}$ & $\Delta \mathrm{E}$ \\
\hline \multirow[t]{4}{*}{0} & Control & $82.8 \pm 0.4 \mathrm{a}$ & $0.2 \pm 0.7 \mathrm{a}$ & $14 \pm 1 b$ & $21.4 \pm 0.4 \mathrm{~b}$ \\
\hline & $\mathrm{CH}$ & $83.3 \pm 0.7 a$ & $-0.2 \pm 0.7 \mathrm{a}$ & $13.9 \pm 0.6 b$ & $21 \pm 1 c$ \\
\hline & GT-PS & $81.8 \pm 0.2 b$ & $0.4 \pm 0.8 \mathrm{a}$ & $16.0 \pm 0.5 \mathrm{a}$ & $23.3 \pm 0.5 \mathrm{a}$ \\
\hline & CH-GT-PS & $81 \pm 1 \mathrm{c}$ & $-0.5 \pm 0.6 \mathrm{a}$ & $15.2 \pm 0.8 \mathrm{a}$ & $23.6 \pm 0.9 \mathrm{a}$ \\
\hline \multirow[t]{4}{*}{8} & Control & $83.1 \pm 0.9 \mathrm{a}$ & $0.7 \pm 0.5 \mathrm{a}$ & $15 \pm 2 b$ & $22 \pm 1 c$ \\
\hline & $\mathrm{CH}$ & $83 \pm 1 \mathrm{ab}$ & $0.4 \pm 0.4 \mathrm{a}$ & $14.1 \pm 0.7 \mathrm{~b}$ & $22 \pm 1 c$ \\
\hline & GT-PS & $81.8 \pm 0.6 b$ & $0 \pm 1 \mathrm{a}$ & $16.3 \pm 0.4 \mathrm{a}$ & $23.5 \pm 0.7 b$ \\
\hline & CH- GT-PS & $80 \pm 1 c$ & $-1.5 \pm 0.5 b$ & $16.1 \pm 0.8 \mathrm{a}$ & $25 \pm 1 \mathrm{a}$ \\
\hline \multirow[t]{4}{*}{16} & Control & $82 \pm 1 \mathrm{ab}$ & $-1 \pm 1 \mathrm{a}$ & $25 \pm 3 a$ & $30 \pm 2 \mathrm{a}$ \\
\hline & $\mathrm{CH}$ & $82 \pm 1 \mathrm{a}$ & $-0.1 \pm 0.6 \mathrm{a}$ & $16 \pm 1 b$ & $23 \pm 1 b$ \\
\hline & GT-PS & $80 \pm 1 b$ & $-1 \pm 1 \mathrm{a}$ & $23 \pm 2 \mathrm{a}$ & $29 \pm 2 \mathrm{a}$ \\
\hline & CH- GT-PS & $81 \pm 1 \mathrm{ab}$ & $0 \pm 1 \mathrm{a}$ & $16.5 \pm 0.7 b$ & $24.4 \pm 0.8 \mathrm{~b}$ \\
\hline \multirow[t]{4}{*}{20} & Control & $75 \pm 3 b$ & $2 \pm 2 \mathrm{a}$ & $36 \pm 5 \mathrm{a}$ & $42 \pm 3 \mathrm{a}$ \\
\hline & $\mathrm{CH}$ & $80 \pm 2 \mathrm{a}$ & $-4 \pm 3 b$ & $22 \pm 3 b$ & $29 \pm 3 b$ \\
\hline & GT-PS & $78 \pm 2 \mathrm{ab}$ & $-7 \pm 3 b$ & $35 \pm 2 \mathrm{a}$ & $41 \pm 2 \mathrm{a}$ \\
\hline & CH- GT-PS & $79 \pm 2 \mathrm{a}$ & $-7 \pm 2 b$ & $25 \pm 3 b$ & $33 \pm 2 b$ \\
\hline
\end{tabular}

Different letters $(a, b, c)$ in the same column indicate $\mathrm{p}<0.05$ significant differences.

Table 2. Effects of green tea extracts, potassium sorbate and chitosan coating on quality parameters of fresh-cut Chinese water chestnut.

\begin{tabular}{lccc}
\hline \multicolumn{1}{c}{ Treatments } & $\begin{array}{c}\text { Soluble } \\
\text { solid }(\%)\end{array}$ & $\begin{array}{c}\text { Titration acid } \\
(\mathrm{g} \text { malic acid/100 g) }\end{array}$ & $\begin{array}{c}\text { Ascorbic acid } \\
(\mathrm{mg} / 100 \mathrm{~g})\end{array}$ \\
\hline Before storage & $11.5 \pm 0.4 \mathrm{a}$ & $0.17 \pm 0.04 \mathrm{a}$ & $7.3 \pm 0.1 \mathrm{a}$ \\
After 20d storage & & & \\
$\quad$ Control & $8.2 \pm 0.5 \mathrm{c}$ & $0.14 \pm 0.04 \mathrm{~b}$ & $6.3 \pm 0.1 \mathrm{c}$ \\
CH & $9.8 \pm 0.3 \mathrm{bc}$ & $0.15 \pm 0.02 \mathrm{ab}$ & $6.9 \pm 0.1 \mathrm{~b}$ \\
GT-PS & $9.4 \pm 0.4 \mathrm{bc}$ & $0.15 \pm 0.02 \mathrm{ab}$ & $6.8 \pm 0.1 \mathrm{bc}$ \\
CH-GT-PS & $10.6 \pm 0.8 \mathrm{~b}$ & $0.16 \pm 0.02 \mathrm{ab}$ & $7.0 \pm 0.1 \mathrm{~b}$ \\
\hline
\end{tabular}

$\mathrm{CH}=$ chitosan; GT-PS = green tea polyphenols-potassium sorbate; CH-GT-PS = chitosan-green tea polyphenols-potassium sorbate. Different letters $(\mathrm{a}, \mathrm{b}, \mathrm{c})$ in the same column indicate $\mathrm{p}<0.05$ significant differences.

tea extracts. With the extension of storage time, $b^{*}$ increased from 14 to 36 , while $\mathrm{L}^{*}$ decreased from 82.8 to 75 during $20 \mathrm{~d}$ storage in the control. Chitosan coating $(\mathrm{CH}$ and $\mathrm{CH}-\mathrm{GT}-\mathrm{PS})$ significantly $(\mathrm{P}<0.05)$ inhibited the increase of $\mathrm{b}^{*}$ and delayed the decrease of $\mathrm{L}^{*}$ compared to the other treatments. It could be related to the amino group in chitosan which had the ability to remove the reactive oxygen free radicals, thus reduced lipid peroxidation level of cell membrane and delayed the browning (No et al., 2007).

Values are expressed as means \pm standard error. Different letters in the same column indicate significant differences $(\mathrm{p}<0.05)$.

As shown in Table 2, all the treatments delayed the decrease of soluble solid, titration acid and ascorbic acid of Chinese water chestnuts after $20 \mathrm{~d}$ storage. However, no significant $(\mathrm{P}>0.05)$ difference was found between the control and the groups treated with $\mathrm{CH}$ and GT-PS in soluble solid content compared with the control. But CH-GT-PS significantly delayed $(\mathrm{P}<0.05)$ the decrease of soluble solid after $20 \mathrm{~d}$ storage. In addition, there was no significant $(P>0.05)$ difference was found between the control and treatments in titration acid, while all the treatments delayed the decrease of ascorbic acid. Soluble solid and organic acid were substrates that were consumed by respiration and metabolic pathway during storage (Özden \& Bayindirli, 2002). In this study, chitosan, green tea polyphenols and potassium sorbate were more effective to delay the decrease of soluble solid and ascorbic acid, and maintain the good quality of fresh-cut CWC during cold storage.

\section{Conclusions}

The cells filled with starch granules in CWC were arranged closely. The water-holding capacity was weak and more free water was found in the tuber cells. Disaccharide (sucrose) was the main sugar in the tuber of CWC compared with monosaccharide. In addition, chitosan, potassium sorbate and green tea polyphenols composite coating demonstrated the better anti-browning effects on the fresh-cut CWC. Tubers treated with chitosan composite coating had lower weight loss and decay index, higher soluble solids and ascorbic acid content.

\section{Acknowledgements}

The authors would like to thank China Postdoctoral Science Foundation (No. 2016M592228) and Shandong Provincial Natural Science Foundation, China (No. ZR2016CL19, No. ZR2017MC051) for partially support of this study.

\section{References}

Ali, A., Muhammad, M. T. M., Sijam, K., \& Siddiqui, Y. (2010). Potential of chitosan coating in delaying the postharvest anthracnose (Colletotrichum gloeosporioides Penz.) of Eksotika II papaya. International Journal of Food Science \& Technology, 45(10), 21342140. http://dx.doi.org/10.1111/j.1365-2621.2010.02389.x.

Bancirova, M. (2010). Comparison of the antioxidant capacity and the antimicrobial activity of black and green tea. Food Research International, 43(5), 1379-1382. http://dx.doi.org/10.1016/j. foodres.2010.04.020. 
Chen, Y., Huang, S., Tang, Z., Chen, X., \& Zhang, Z. (2011). Structural changes of cassava starch granules hydrolyzed by a mixture of $\alpha-$ amylase and glucoamylase. Carbohydrate Polymers, 85(1), 272-275. http://dx.doi.org/10.1016/j.carbpol.2011.01.047.

Füzfai, Z., Katona, Z. F., Kovács, E., \& Molnár-Perl, I. (2004). Simultaneous identification and quantification of the sugar, sugar alcohol, and carboxylic acid contents of sour cherry, apple, and ber fruits, as their trimethylsilyl derivatives, by gas chromatography-mass spectrometry. Journal of Agricultural and Food Chemistry, 52(25), 7444-7452. http://dx.doi.org/10.1021/jf040118p. PMid:15675786.

Gonzalez, J. J., Valle, R. C., Bobroff, S., Biasi, W. V., Mitcham, E. J., \& McCarthy, M. J. (2001). Detection and monitoring of internal browning development in 'Fuji' apples using MRI. Postharvest Biology and Technology, 22(2), 179-188. http://dx.doi.org/10.1016/ S0925-5214(00)00183-6.

Hosseinnejad, M., \& Jafari, S. M. (2016). Evaluation of different factors affecting antimicrobial properties of chitosan. International Journal of Biological Macromolecules, 85, 467-475. http://dx.doi.org/10.1016/j. ijbiomac.2016.01.022. PMid:26780706.

Jiang, Y., Pen, L., \& Li, J. (2004). Use of citric acid for shelf life and quality maintenance of fresh-cut Chinese water chestnut. Journal of Food Engineering, 63(3), 325-328. http://dx.doi.org/10.1016/j. jfoodeng.2003.08.004.

Klockeman, D. M., Pressey, R., \& Jen, J. J. (1991). Characterization of cell wall polysaccharides of jicama (Pachyrrhizus erosus) and Chinese water chestnut (Eleocharis dulicis). Journal of Food Biochemistry, 15(5), 317-329. http://dx.doi.org/10.1111/j.1745-4514.1991.tb00418.x.

Liu, J., Tian, S., Meng, X., \& Xu, Y. (2007). Effects of chitosan on control of postharvest diseases and physiological responses of tomato fruit. Postharvest Biology and Technology, 44(3), 300-306. http://dx.doi. org/10.1016/j.postharvbio.2006.12.019.

Mudahar, G. S., \& Jen, J. J. (1991). Texture of raw and canned jicama (Pachyrrhizus tuberosus) and Chinese water chestnut (Eleocharis dulcis). Journal of Food Science, 56(4), 977-980. http://dx.doi. org/10.1111/j.1365-2621.1991.tb14620.x.

No, H. K., Meyers, S. P., Prinyawiwatkul, W., \& Xu, Z. (2007). Applications of chitosan for improvement of quality and shelf life of foods: a review. Journal of Food Science, 72(5), 87-100. http://dx.doi. org/10.1111/j.1750-3841.2007.00383.x. PMid:17995743.

Ojagh, S. M., Rezaei, M., Razavi, S. H., \& Hosseini, S. M. H. (2010). Development and evaluation of a novel biodegradable film made from chitosan and cinnamon essential oil with low affinity toward water. Food Chemistry, 122(1), 161-166. http://dx.doi.org/10.1016/j. foodchem.2010.02.033.

Özden, Ç., \& Bayindirli, L. (2002). Effects of combinational use of controlled atmosphere, cold storage and edible coating applications on shelf life and quality attributes of green peppers. European Food Research and Technology, 214(4), 320-326. http://dx.doi.org/10.1007/ s00217-001-0448-z.

Pan, Y. G., Li, Y. X., \& Yuan, M. Q. (2015). Isolation, purification and identification of etiolation substrate from fresh-cut Chinese waterchestnut (Eleocharis tuberosa). Food Chemistry, 186, 119-122. http:// dx.doi.org/10.1016/j.foodchem.2015.03.070. PMid:25976800.
Park, S. I., Stan, S. D., Daeschel, M. A., \& Zhao, Y. Y. (2005). Antifungal coatings on fresh strawberries (Fragaris $\times$ ananassa) to control mold growth during cold storage. Journal of Food Science, 70(4), 202-207. http://dx.doi.org/10.1111/j.1365-2621.2005.tb07189.x.

Peng, L., \& Jiang, Y. (2006). Exogenous salicylic acid inhibits browning of fresh-cut Chinese water chestnut. Food Chemistry, 94(4), 535-540. http://dx.doi.org/10.1016/j.foodchem.2004.11.047.

Peng, L., Yang, S., Li, Q., Jiang, Y., \& Joyce, D. C. (2008). Hydrogen peroxide treatments inhibit the browning of fresh-cut Chinese water chestnut. Postharvest Biology and Technology, 47(2), 260-266. http:// dx.doi.org/10.1016/j.postharvbio.2007.07.002.

Peng, Y., Li, Y., \& Yin, L. (2013). Effects of edible coatings on some quality parameters of Chinese water chestnut (Eleocharis tuberosa) during storage. International Journal of Food Science \& Technology, 48(7), 1404-1409. http://dx.doi.org/10.1111/ijfs.12102.

Picha, D. H. (1985). HPLC determination of sugars in raw and baked sweet potatoes. Journal of Food Science, 50(4), 1189-1190. http:// dx.doi.org/10.1111/j.1365-2621.1985.tb13045.x.

Taghvaei, M., Jafari, S. M., Mahoonak, A. S., Nikoo, A. M., Rahmanian, N., Hajitabar, J., \& Meshginfar, N. (2014). The effect of natural antioxidants extracted from plant and animal resources on the oxidative stability of soybean oil. Lebensmittel-Wissenschaft + Technologie, 56(1), 124-130. http://dx.doi.org/10.1016/j.lwt.2013.11.009.

Wang, L., Yin, Z., Wu, J., Sun, Z., \& Xie, B. (2008). A study on freezethaw characteristics and microstructure of Chinese water chestnut starch gels. Journal of Food Engineering, 88(2), 186-192. http://dx.doi. org/10.1016/j.jfoodeng.2008.02.005.

Werz, K., Braun, H., Vitha, D., Bruno, G., Martirosian, P., Steidle, G., \& Schick, F. (2011). Relaxation times T1, T2, and T2* of apples, pears, citrus fruits, and potatoes with a comparison to human tissues. Zeitschrift fur Medizinische Physik, 21(3), 206-215. http://dx.doi. org/10.1016/j.zemedi.2010.12.006. PMid:21530199.

Winisdorffer, G., Musse, M., Quellec, S., Barbacci, A., Gall, S. L., Mariette, F., \& Lahaye, M. (2015). Analysis of the dynamic mechanical properties of apple tissue and relationships with the intracellular water status, gas distribution, histological properties and chemical composition. Postharvest Biology and Technology, 104, 1-16. http:// dx.doi.org/10.1016/j.postharvbio.2015.02.010.

Wu, S. J., \& Yu, L. (2015). Preparation and characterisation of the oligosaccharides derived from Chinese water chestnut polysaccharides. Food Chemistry, 181, 15-18. http://dx.doi.org/10.1016/j. foodchem.2015.02.066. PMid:25794714.

Zhang, D., \& Quantick, P. C. (1997). Effects of chitosan coating on enzymatic browning and decay during postharvest storage of litchi (Litchi chinensis Sonn.) fruit. Postharvest Biology and Technology, 12(2), 195-202. http://dx.doi.org/10.1016/S0925-5214(97)00057-4.

Zhou, R., Mo, Y., Li, Y., Zhao, Y., Zhang, G., \& Hu, Y. (2008). Quality and internal characteristics of Huanghua pears (Pyrus pyrifolia Nakai, cv. Huanghua) treated with different kinds of coatings during storage. Postharvest Biology and Technology, 49(1), 171-179. http:// dx.doi.org/10.1016/j.postharvbio.2007.12.004. 